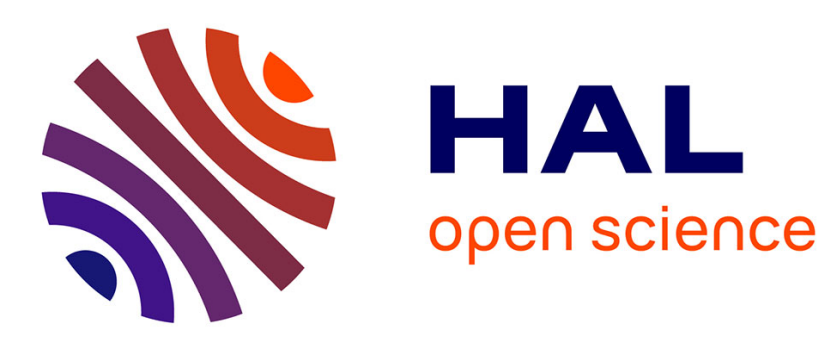

\title{
Managing weeds with a dualistic approach of prevention and control. A review
}

Randy L. Anderson

\section{To cite this version:}

Randy L. Anderson. Managing weeds with a dualistic approach of prevention and control. A review. Agronomy for Sustainable Development, 2007, 27 (1), pp.13-18. hal-00886387

\section{HAL Id: hal-00886387 https://hal.science/hal-00886387}

Submitted on 1 Jan 2007

HAL is a multi-disciplinary open access archive for the deposit and dissemination of scientific research documents, whether they are published or not. The documents may come from teaching and research institutions in France or abroad, or from public or private research centers.
L'archive ouverte pluridisciplinaire HAL, est destinée au dépôt et à la diffusion de documents scientifiques de niveau recherche, publiés ou non, émanant des établissements d'enseignement et de recherche français ou étrangers, des laboratoires publics ou privés. 


\title{
Managing weeds with a dualistic approach of prevention and control. A review
}

\author{
Randy L. ANDERSON* \\ USDA, 2923 Medary Avenue, Brookings, South Dakota, USA
}

(Accepted 2 October 2006)

\begin{abstract}
Scientists have theorized that weed management would be more efficient if prevention tactics were integrated with control tactics. The goals of prevention are to reduce weed community density and improve crop tolerance to weeds. Here we describe the impact of this approach in the semiarid steppe of the United States. As a result, producers have reduced herbicide inputs and costs by $50 \%$ compared to conventional practices. Critical factors for success with this approach are rotation design and no-till practices. Rotations comprised of two cool-season crops followed by two warm-season crops are the most disruptive of weed population growth. The impact of rotation design on weed community density is enhanced by no-till. Crop tolerance to weeds is improved by systems of cultural tactics. The tolerance is greatest when three tactics are combined together. This dualistic approach of prevention and control effectively controls weeds with four-crop rotations such that herbicides are not needed in some crops of the rotation. Weed density is so low that crop yield is not affected by weed interference. With this approach, herbicides are a choice rather than a requirement for cropping success in the semiarid steppe of the United States.
\end{abstract}

crop diversity / rotation design / no-till / United States

\section{INTRODUCTION}

Producers in the United States are fortunate to have a vast arsenal of herbicides to control weeds. Because herbicides were initially so effective, producers and scientists perceived herbicides as the "silver bullet", controlling weeds with one management tactic. Herbicide-based control, however, has failed to achieve long-term weed management (Mortensen et al., 2000; Weber and Gut, 2005). Even with herbicides, weeds remain prominent in croplands and producers still lose considerable crop yield due to weeds (Bridges, 1994). Furthermore, herbicide resistance is forcing producers to use more expensive management tactics, thereby increasing production costs. Thus, scientists and producers in the United States are seeking a broader perspective to weed management than relying primarily on herbicides (Lewis et al., 1997). One possible approach is expanding management tactics to include a prevention component (Pedigo, 1995; Ferron and Deguine, 2005). Prevention tactics are planned to disrupt weed population growth, with one effective tactic being rotations comprised of crops with different life cycles (Streibig, 1979).

No-till practices have begun about 30 years ago in Brazil primarily as a means of reducing soil erosion (Bernoux et al., 2006). At present, about 63 million ha are under no-till systems worldwide, with the USA having the largest area of about 21 million ha, following by Brazil with about 20 million ha (Bernoux et al., 2006). In the semiarid steppe of the United States, crop rotations are changing because of no-till practices. Previously, producers followed a winter wheat (Triticum

\footnotetext{
* Corresponding author: randerson@ ngirl.ars.usda.gov
}

aestivum L.)-fallow rotation. During fallow, neither crops nor weeds are allowed to grow. Therefore, precipitation during the fallow interval is stored in soil for future crop use. Soil water gained during fallow reduces yield variability and crop loss due to drought stress. However, preserving crop residues on the soil surface with no-till has increased precipitation storage in soil such that more crops can be grown before fallow is needed again (Farahani et al., 1998). Producers now grow warm-season crops such as corn (Zea mays L.), proso millet (Panicum miliaceum L.), sorghum [Sorghum bicolor (L.) Moench] and sunflower (Helianthus annuus L.) along with cool-season crops such as winter wheat and dry pea (Pisum sativum L.) (Anderson et al., 1999).

This diversity in crops with different life cycles provided an opportunity for producers to develop weed management systems that integrate prevention with control tactics (Fig. 1). For prevention, cultural tactics are used to reduce weed community density and improve crop tolerance to weed interference. Another suite of tactics controls weeds in crops. This approach enables producers to effectively control weeds with $50 \%$ less cost compared with producers using less diverse rotations or the conventional system of winter wheat-fallow (Anderson, 2005a).

With this paper, we explain the cultural tactics and ecological reasoning that led to this dualistic approach with weed management in the semiarid steppe of the United States. Our example may provide insight and ideas for producers and scientists elsewhere to develop similar programs. Even though crop choices and cultural tactics can vary among regions, 


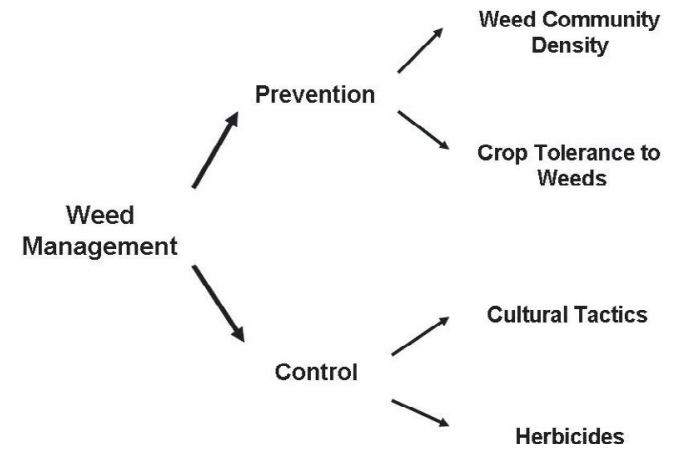

Figure 1. A conceptual framework for developing a broader perspective with weed management that integrates prevention with control tactics (Adapted from concepts described in Pedigo, 1995).

integrating prevention tactics with control tactics may lead to successful weed management less dependent on herbicides.

\subsection{Weed community in the semiarid steppe}

In the United States steppe, annual weeds are the prevalent species infesting grain crops. The weed community includes cool-season weeds such as downy brome (Bromus tectorum L.), jointed goatgrass (Aegilops cylindrica Host), kochia [Kochia scoparia (L.) Schrad.], and Russian thistle (Salsola iberica Sennen \& Pau). These weeds emerge during the cooler months of the growing season, either in September and October or late March through early May. Prominent warmseason weeds are green foxtail [Setaria viridis (L.) Beauv.], field sandbur [Cenchrus longispinus (Hack.) Fern.], stinkgrass [Eragrostis cilianensis (All.) E. Mosher] and redroot pigweed (Amaranthus retroflexus L.), which emerge during mid-May through July. Less than $1 \%$ of the land area is infested with perennial weeds.

\section{PREVENTION: REDUCING WEED COMMUNITY DENSITY}

With annual weeds, the seed is the key component of population dynamics. Strategies for prevention emphasize cultural tactics that decrease the number of weed seeds in soil, reduce weed seedling establishment, and minimize seed production by plants that escape control tactics (Fig. 2). Cultural tactics can be grouped into five categories: rotation design, crop sequencing, no-till, crop residue management, and competitive crop canopies. In the following text, we describe tactics used for each category and their impact on weed dynamics.

\subsection{Arranging cool-season and warm-season crops in rotation}

Both cool- and warm-season crops are commonly grown in the region. Different planting and harvest dates among these

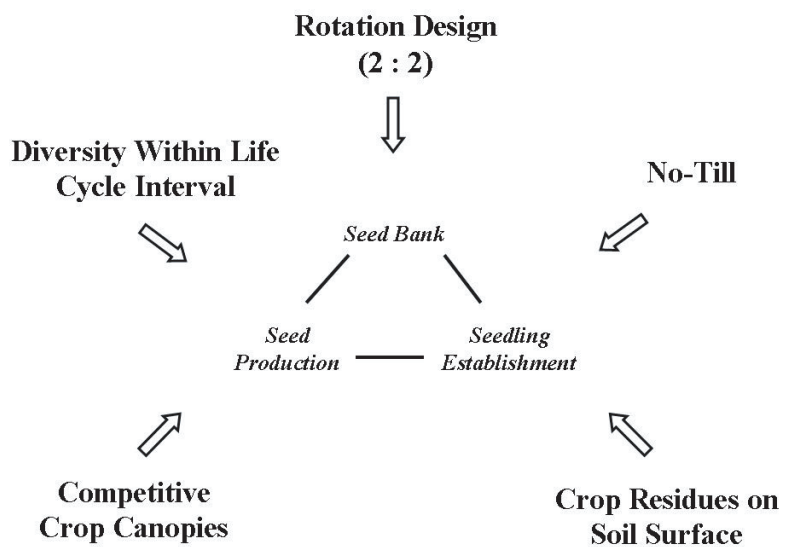

Figure 2. Five components of a prevention approach to reduce weed community density in the semiarid steppe of the United States. The $2: 2$ designation refers to rotations comprised of two cool-season crops followed by two warm-season crops. Cultural tactics in each component disrupt weed population dynamics by minimizing weed seed survival in soil (seed bank), seedling establishment, or seed production (Adapted from Anderson, 2005a).

crops provide more opportunities for producers to prevent either plant establishment or seed production by weeds. For example, green foxtail emerges between mid-May and early July, then begins flowering in early August. Winter wheat is harvested in early July, thus producers can control green foxtail before it flowers and produces seeds. A similar opportunity occurs with cool-season weeds; they are easily controlled before planting warm-season crops such as corn or sunflower to prevent seed production.

The impact of rotations on weed community density is related to seed survival in soil. With downy brome and green foxtail, approximately $20 \%$ of seeds are alive one year after seed shed, whereas less than $5 \%$ of their seeds are alive after two years (Anderson, 2003). Rotating crops with different life cycles favors the natural loss of weed seeds across time because producers can prevent new seeds being added to the soil. With less seeds in the soil, fewer seedlings emerge in following crops (Sagar and Mortimer, 1976; Roberts, 1981).

However, long-term rotation studies using conventional herbicide programs show a striking trend; weed density increases if rotations consist of one cool-season crop followed by one warm-season crop, such as winter wheat-proso millet (Anderson, 2005a). In contrast, if rotations are arranged in a cycle of four, with two cool-season crops followed by two warm-season crops, weed density declines with time. Comparing trends across three rotation studies, weed seedling density was eightfold higher in two-crop rotations compared with four-crop rotations comprised of cool- and warm-season crops.

Another trend noted with long-term rotation studies is that with four-crop rotations, weed density increases if the same crop is grown two years in a row (Anderson, 2003). When winter wheat is grown two years in a row, density of the winter annual grasses, downy brome and jointed goatgrass, escalate rapidly. Seed decay of weeds in the soil is minimal during the 


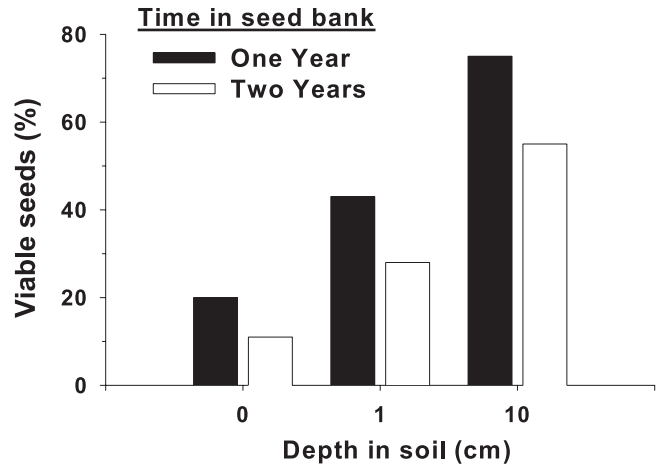

Figure 3. Impact of depth in soil on seed survival of green foxtail. Means for each depth within each year differ as determined by 95\% confidence intervals. Study conducted in the semiarid prairies of Canada (Adapted from Banting et al., 1973; Thomas et al., 1986).

3-month interval between winter wheat harvest and planting, thus seedling emergence is high in the second winter wheat crop. In contrast, replacing one crop of winter wheat with another cool-season crop, such as dry pea, provides an opportunity to reduce seedlings of winter annual weeds that emerge over winter because dry pea is planted in late March or early April.

A similar benefit occurs when a warm-season sequence of corn and sunflower is used rather than two years of corn; corn is planted in early May whereas sunflower is planted 3 to 4 weeks later. Diversifying crops with different planting dates within a life-cycle category, i.e., warm-season crops, accentuates the benefit gained with rotations comprised of twoyear intervals of cool- and warm-season crops. Examples of four-year rotations used in the region are winter wheat-cornsunflower-fallow or dry pea-winter wheat-corn-proso millet; like sunflower, proso millet is planted 3 to 4 weeks later than corn.

\subsection{No-till interacts with rotation design to affect weed density}

No-till systems help weed management by keeping weed seeds near the soil surface and exposing seeds to environmental extremes and predation (Sagar and Mortimer, 1976). For example, a study in the Canadian prairies showed that more than $50 \%$ of green foxtail seeds were alive after two years when buried $10 \mathrm{~cm}$ in soil, contrasting with less than $10 \%$ of seeds surviving when they remained on the soil surface (Fig. 3 ). Even when seeds were buried only $1 \mathrm{~cm}$ in soil, survival was still two-fold greater after two years compared with seeds on the soil surface.

The impact of no-till on weed seed survival in soil, however, is related to rotation design. This relationship was demonstrated with a series of studies that recorded weed seedling emergence in no-till and tilled treatments for three years (Anderson, 2005a). The sites were naturally infested with weeds, but after initiation of each study, further weed seed rain was prevented. Averaged across all studies, seedling emer-

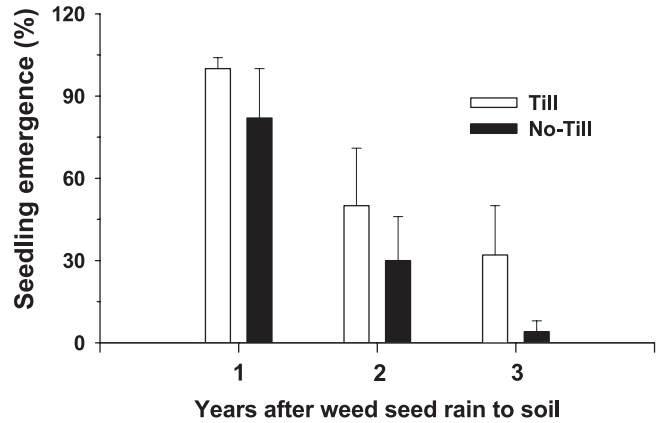

Figure 4. Effect of tillage on weed seedling emergence across time. Weed seeds were not added to the soil after initiation of studies; tillage occurred in the tilled treatment each year. Data expressed as a percentage of the treatment with highest number of weed seedlings in each study. Standard error bars were derived from yearly means among studies (Adapted from Egley and Williams, 1990; Popay et al., 1994; Anderson, 1998).

gence was similar between tilled and no-till in the first year, whereas in the second year, the difference between tillage treatments was about twofold (Fig. 4). In contrast, seedling emergence was eightfold greater with the tilled system in the third year; the benefit of no-till in reducing seedling emergence increased across time.

This interaction among seedling emergence, tillage, and time is one reason why no-till rotations with two-year intervals of cool- and warm-season crops are effective in reducing weed density. By preventing weed seed production across two years, such as eliminating seed rain of cool-season weeds during the warm-season crop interval, weed seedling density is drastically reduced when a cool-season crop is grown in the third year with no-till.

Rotation design also helps weed management in tilled systems, but the impact is less compared with no-till systems (Anderson, 2004). The reason tillage reduces the rotation effect on weed density is that weed seeds survive longer when buried in soil, thus leading to more weed seedlings in following years (Sagar and Mortimer, 1976).

A further benefit of no-till is that crop residues lying on the soil surface reduce establishment of weed seedlings; in the semiarid steppe, each $1000 \mathrm{~kg} / \mathrm{ha}$ of winter wheat residues on the soil surface reduces weed seedling establishment $14 \%$ (Wicks et al., 1994). To enhance crop residue suppression of weed emergence, producers grow taller cultivars of winter wheat at seeding rates 50\% higher than normal, with low rates of $\mathrm{N}$ and $\mathrm{P}$ banded with the seed at planting. These tactics increase residue production 2000 to $2500 \mathrm{~kg} / \mathrm{ha}$ (Anderson, 2003). Similar suppression of weed establishment occurs with residues of other crops.

\subsection{Competitive crop canopies reduce weed growth and seed production}

To minimize seed production of weeds that escape control tactics in crops, crop competitiveness to weeds is increased 


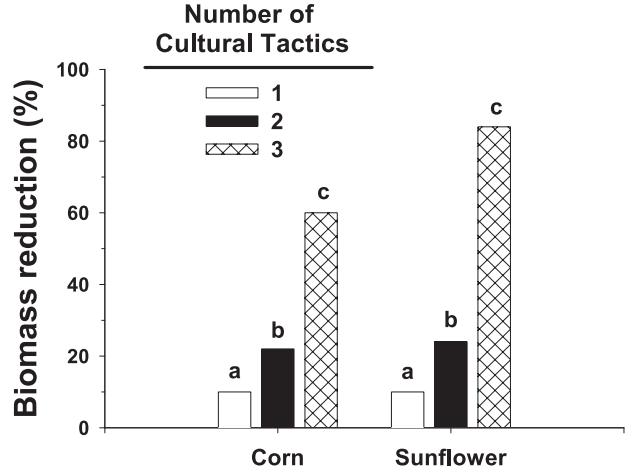

Figure 5. Synergism of cultural tactics with suppression of weed biomass in corn and sunflower. Tactics include increased seeding rates, narrower row spacing, fertilizer placement, and delayed planting, with treatments compared to the conventional system used by producers. Bars with an identical letter within a crop are not significantly different based on Fisher's Protected LSD (0.05). Means for single tactic treatments did not differ from the conventional system. Study conducted at Akron, Colorado, United States (Adapted from Anderson, 2003).

with cultural tactics such as increased seeding rate or fertilizer placement. A key to effectiveness, however, is that several tactics need to be combined (Anderson, 2003). With sunflower, a single cultural tactic, such as narrower row spacing, higher plant population, or delayed planting, reduced weed biomass 5 to $10 \%$ compared to conventional practices used by producers (Fig. 5). When two practices were combined, biomass suppression approached 20 to $25 \%$. However, weed biomass was reduced almost $90 \%$ when three tactics were integrated together. Combining tactics synergistically enhanced sunflower suppression of weed growth. A similar trend occurred with corn and higher plant population, narrow row spacing, and fertilizer placement; again, a system of three cultural tactics greatly reduced weed growth (Fig. 5).

This synergistic trend with cultural tactics in suppressing weed growth also occurs with proso millet and winter wheat (Anderson, 2003). With proso millet, a cultural system comprised of a tall cultivar, higher seeding rate, and $\mathrm{N}$ banding by the seed, reduced seed production of redroot pigweed $90 \%$ compared with conventional practices (Anderson, 2000a).

\section{PREVENTION: IMPROVING CROP TOLERANCE TO WEED INTERFERENCE}

Along with reducing weed density, a second component of prevention is improving crop tolerance to weeds (Fig. 1). Earlier, we discussed cultural systems in corn that reduced weed growth (Fig. 5); this approach also improves corn tolerance to weeds (Anderson, 2000b). Common practices for growing corn in the semiarid steppe include a target population of 37000 plants/ha, row spacing of $76 \mathrm{~cm}$, and $\mathrm{N}$ fertilizer applied broadcast. To assess corn tolerance to weeds, we evaluated three cultural tactics: (1) banding $\mathrm{N}$ near the seed; (2) higher corn density (47000 plants/ha); and (3) nar-

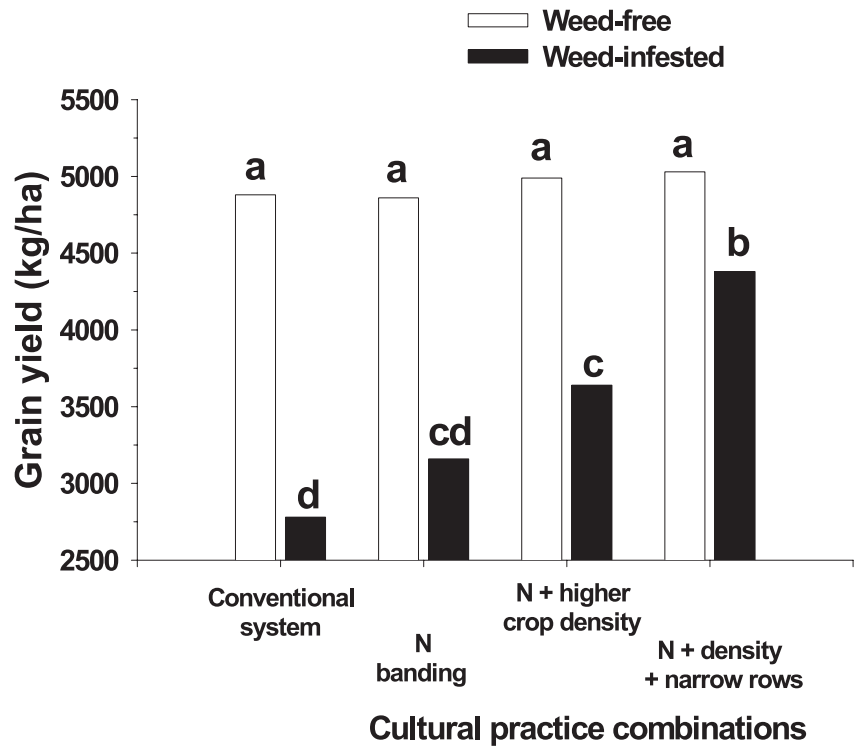

Figure 6. Corn grain yield in weed-free and weed-infested conditions as affected by cultural tactic combinations. Conventional system was 37000 plants/ha at a row spacing of $76 \mathrm{~cm}$, with $\mathrm{N}$ fertilizer broadcast at planting. Cultural tactics were banding $\mathrm{N}$ near the seed, increasing crop density to 47000 plants/ha, and reducing row spacing to $38 \mathrm{~cm}$. Data averaged across three years; bars with the same letter are not significantly different based on Fisher's Protected LSD (0.05). Study conducted at Akron, Colorado, United States (Adapted from Anderson, 2000b).

row row spacing $(38 \mathrm{~cm})$. All possible combinations of these tactics were evaluated, with the study established in no-till. The conventional system comprised of common practices was included for comparison, and treatments were split into weedfree and weed-infested subplots.

Yield loss due to weed interference was only $13 \%$ when three cultural tactics were combined (Fig. 6). In contrast, yield loss was $43 \%$ with the conventional system, a three-fold increase compared to the production system with three cultural tactics. If only one or two cultural tactics were used, yield loss due to weed interference was still reduced, but not to the extent of combining three cultural tactics.

We achieved similar results with improving proso millet tolerance to weeds (Anderson, 2000a). A cultural system comprised of a tall cultivar, seeding rate increased $50 \%$ above normal, and banding $\mathrm{N}$ fertilizer near the seed, was established with no-till. The conventional system used by producers was established with tillage and $\mathrm{N}$ fertilizer applied broadcast. Each treatment was split into weed-free and weed-infested subplots.

The cultural system eliminated yield loss due to weed interference whereas weeds reduced grain yield $29 \%$ in the conventional system. Yield differences reflected system impact on weed biomass, which was nine-fold greater with the conventional system. Cultural systems also improve tolerance of winter wheat and sunflower to weeds (Anderson, 2003). 


\section{CONTROL: BENEFITS GAINED WITH PREVENTION TACTICS}

Producers gain a multitude of benefits with lower weed community density and more crop tolerance to weed interference. Herbicide efficacy is improved whereas cultural tactics become a more viable alternative to herbicides. Lower weed density reduces the need for herbicides to manage weeds.

\subsection{Improved herbicide performance}

Both soil- and foliar-applied herbicides are more effective at lower weed density (Winkle et al., 1981). For example, Dieleman et al. (1999) found that number of broadleaf weeds surviving treatment of foliar-applied herbicides was related to initial density of plants. Hoffman and Lavy (1978) reported a similar trend with weed density and atrazine activity in soil; more plants escaped control at higher densities.

Increasing crop competitiveness with cultural tactics also improves herbicide efficacy (Derksen et al., 2002; O'Donovan et al., 2006). Scientists in the Netherlands are defining the minimum lethal herbicide dose needed for efficient weed control in various crops (Mortensen et al., 2000); lower weed density and improved crop competitiveness should enhance success of this approach also.

\subsection{Reduced input costs}

The economic impact of the dualistic approach to weed management in the semiarid steppe was determined by comparing eight producers who followed this approach with eight conventional producers (Anderson, 2005a). Producers who included prevention tactics in weed management reduced herbicide inputs and cost 50\% compared with producers following conventional practices. Cost of weed management was less because lower weed community density reduces the need for herbicides. With winter wheat-corn-proso millet-fallow, producers grow winter wheat and proso millet without in-crop herbicides; weed density is so low that crop yield is not affected by weeds.

A second trend noted with this economic survey is that net returns were fourfold greater for producers with diverse rotations compared with conventional producers. The dualistic approach for weed management was a key factor with improved economics; savings in weed management costs comprised one half of the increase with net returns by producers using crop diversity and no-till rotations.

\subsection{Cultural tactics as alternatives to herbicides}

Cultural tactics can effectively substitute for herbicides if weed density is low (Forcella et al., 1993). As noted earlier, a system comprised of three cultural tactics to improve competitiveness of proso millet eliminated yield loss due to weeds; in contrast, weed interference reduced yield $29 \%$ with the conventional system used by producers (Anderson, 2000a). A similar benefit was achieved with sunflower; yield loss was eliminated with a system of cultural tactics whereas weed interference reduced yield $24 \%$ with the conventional system (Anderson, 2003).

Weed management in crops grown in wide rows $(76 \mathrm{~cm}$ or more), such as corn, often require high herbicide or tillage inputs to control weeds. Recent advances with weed control equipment may provide an alternative to herbicides or tillage. An in-row cultivator has been developed that effectively removes weeds in the corn row, especially in fields with low weed seedling density (Schweizer et al., 1992). In addition, a mower has been developed that controls weeds between rows of soybean (Glycine max L.) and corn (Donald et al., 2001). With lower weed community densities due to prevention tactics, a system comprised of these two tactics may control weeds in wide-row crops without herbicides.

\subsection{Ancillary benefits for managing other pests}

Prevention tactics for weed management, such as crop diversity, also helps manage other pests. A prominent example occurs with sunflower. The sunflower stem weevil (Cylindrocopturus adspersus Leconte), a native insect of the steppe, burrows into the stem during the growing season (Knodel and Charlet, 2002). Sunflower tolerates normal infestation levels without yield loss. However, phoma (Phoma macdonaldi Boerma), a native soil-borne fungus, proliferates when sunflower is grown more frequently than once every four years (Anderson, 2005b). Phoma weakens the sunflower stem, thus accentuating the impact of stem weevil injury and leading to extensive lodging before harvest. If phoma is present, producers need to spray insecticides for the stem weevil to prevent severe yield loss. Similar results have been achieved by scientists in the Netherlands, where insects, diseases, and weeds are being managed with less pesticides in cropping systems that include diverse rotations and prevention planning (Lewis et al., 1997).

\section{THE DUALISTIC APPROACH TO WEED MANAGEMENT}

A key aspect of the dualistic approach is that multiple tactics need to be integrated into the production system, as shown with tactics used to reduce weed community density (Fig. 2). Density of weed communities often escalates if management includes only a few tactics, especially when herbicide input is reduced. For example, no-till rotations comprised of only one or two crops (Anderson, 2005a) or cropping systems that include extensive tillage (Anderson, 1999) lead to more weeds. In addition, seed production of weeds escaping control tactics in the crop can minimize the benefits of crop diversity and no-till if cultural tactics are not used to improve crop competitiveness. The dualistic approach to weed management requires more planning and management than the herbicide-based approach. However, the dualistic approach has transformed weed 
management in the semiarid steppe. Producers have found that herbicides are a choice rather than a requirement for cropping success with this approach (Anderson, 2005a). Additionally, eliminating herbicide use in some years is reducing selection pressure for resistant weeds.

\section{REFERENCES}

Anderson R.L. (1998) Seedling emergence of winter annual grasses as affected by limited tillage and crop canopy, Weed Technol. 12, 262267.

Anderson R.L. (1999) Cultural strategies reduce weed densities in summer annual crops, Weed Technol. 13, 314-319.

Anderson R.L. (2000a) A cultural systems approach eliminates the need for herbicides in semiarid proso millet, Weed Technol. 14, 602-607.

Anderson R.L. (2000b) Cultural systems to aid weed management in semiarid corn, Weed Technol. 14, 630-634.

Anderson R.L. (2003) An ecological approach to strengthen weed management in the semiarid Great Plains, Adv. Agron. 80, 33-62.

Anderson R.L. (2004) Impact of sub-surface tillage on weed dynamics in the Central Great Plains, Weed Technol. 18, 186-192.

Anderson R.L. (2005a) A multi-tactic approach to manage weed population dynamics in crop rotations, Agron. J. 97, 1579-1583.

Anderson R.L. (2005b) Improving sustainability of cropping systems in the Central Great Plains, J. Sustain. Agr. 26, 97-114.

Anderson R.L., Bowman R.A., Nielsen D.C., Vigil M.F., Aiken R.M., Benjamin J.G. (1999) Alternative crop rotations for the central Great Plains, J. Prod. Agric. 12, 95-99.

Banting J.D., Molberg E.S., Gephardt J.P. (1973) Seasonal emergence and persistence of green foxtail, Can. J. Plant Sci. 53, 369-376.

Bernoux M., Cerri C.C., Cerri C.E.P., Neto M.S., Metay A., Perrin A.S., Scopel E., Razafimbelo T., Blavet D., Piccolo M.C., Pavei M., Milne E. (2006) Cropping systems, carbon sequestration and erosion in Brazil, a review, Agron. Sustain. Dev. 26, 1-8. DOI: 10.1051/agro:2005055.

Bridges D.C. (1994) Impact of weeds on human endeavors, Weed Technol. 8, 392-395.

Derksen D.A., Anderson R.L., Blackshaw R.E., Maxwell B. (2002) Weed dynamics and management strategies for cropping systems in the Northern Great Plains, Agron. J. 94, 174-185.

Dieleman J.A., Mortensen D.A., Martin A.R. (1999) Influence of velvetleaf (Abutilon theophrasti) and common sunflower (Helianthus апnииs) density variation on weed management outcomes, Weed Sci. 47, 81-87.

Donald W.W., Kitchen N.R., Sudduth K.A. (2001) Between-row mowing plus banded herbicide to control annual weeds and reduce herbicide use in no-till soybean (Glycine max) and corn (Zea mays), Weed Technol. 15, 576-584.

Egley G.H., Williams R.D. (1990) Decline of weed seeds and seedling emergence over five years as affected by soil disturbance, Weed Sci. $38,504-510$
Farahani H.J., Peterson G.A., Westfall D.G. (1998) Dryland cropping intensification: a fundamental solution to efficient use of precipitation, Adv. Agron. 64, 197-223.

Ferron P., Deguine J.P. (2005) Crop protection, biological control, habitat management and integrated farming. A review, Agron. Sustain Dev. 25, 17-24. DOI: 10.1051/agro:2004050.

Forcella F., Eradat-Oskoui K., Wagner S.W. (1993) Application of weed seedbank ecology to low-input crop management, Ecol. Appl. 3, $74-83$.

Hoffman D.W., Lavy T.L. (1978) Plant competition for atrazine, Weed Sci. 26, 94-99.

Knodel J.J., Charlet L.D. (2002) Biology and integrated pest management of the sunflower stem weevil in the Great Plains, North Dakota State University Cooperative Extension Service Bulletin E-821, 8 p.

Lewis W.J., van Lenteren J.G., Phatak S.C., Tumlinson J.H. (1997) A total system approach to sustainable pest management, Proc. Nat. Acad. Sci. (USA) 94, 12243-12248.

Mortensen D.A., Bastiaans L., Sattin M. (2000) The role of ecology in the development of weed management systems: an outlook, Weed Res. 40, 49-62.

O'Donovan J.T., Blackshaw R.E., Harker K.N., Clayton G.W. (2006) Wheat seeding rate influences herbicide performance in wild oat (Avena fatua L.), Agron. J. 98, 815-822.

Pedigo L.P. (1995) Closing the gap between IPM theory and practice, J. Agr. Entomol. 12, 171-181.

Popay A.I., Cox T.I., Ingle A., Kerr R. (1994) Effects of soil disturbance on weed seedling emergence and its long-term decline, Weed Res. $34,403-412$.

Roberts H.A. (1981) Seed banks in soils, Adv. Appl. Biol. 6, 1-55.

Sagar G.R., Mortimer A.M. (1976) An approach to the study of the population dynamics of plants with special reference to weeds. Adv. Appl. Biol. 1, 1-47.

Schweizer E.E., Westra P., Lybecker D.W. (1992) Controlling weeds in corn (Zea mays) rows with an in-row cultivator versus decisions made by a computer model, Weed Sci. 42, 593-600.

Streibig J.C. (1979) Numerical methods illustrating the phytosociology of crops in relation to weed flora, J. Appl. Ecol. 16, 577-587.

Thomas A.G., Banting J.D., Bowes G. (1986) Longevity of green foxtail seeds in a Canadian prairie soil, Can. J. Plant Sci. 66, 189-192.

Weber E., Gut D. (2005) A survey of weeds that are increasingly spreading in Europe, Agron. Sustain. Dev. 25, 109-121. DOI: 10.1051/agro:2004061

Wicks G.A., Crutchfield D.A., Burnside, O.C. (1994) Influence of wheat (Triticum aestivum) straw mulch and metolachlor on corn (Zea mays) growth and yield, Weed Sci. 42, 141-147.

Winkle M.E., Leavitt J.R.C., Burnside O.C. (1981) Effects of weed density on herbicide absorption and bioactivity, Weed Sci. 29, 405-409. 